This is the Accepted Version of an article published by Cambridge University Press in Environmental Conservation Vol 43 (4) December 2016, 359-367. Published version available from:

https://doi.org/10.1017/S0376892916000175

Accepted Version downloaded from SOAS Research Online:

http://eprints.soas.ac.uk/22500/

Tree products, food security and livelihoods: a household study of Burkina Faso

NIGEL POOLE

CENTRE FOR DEVELOPMENT, ENVIRONMENT AND POLICY

SOAS, UNIVERSITY OF LONDON

RUSSELL SQUARE, LONDON WC1H OXG - UK

Email:n.poole@soas.ac.uk

CAMILLA AUDIA

CENTRE FOR DEVELOPMENT, ENVIRONMENT AND POLICY

SOAS, UNIVERSITY OF LONDON

RUSSELL SQUARE, LONDON WC1H OXG - UK

\title{
BARTÉLÉMY KABORET
}

TREEAID (OUAGADOUGOU)

C/O BRUNSWICK COURT

BRUNSWICK SQUARE, BRISTOL S2 8PE - UK

\section{REBECCA KENT}

CHRIST CHURCH CANTERBURY UNIVERSITY

NORTH HOLMES ROAD

CANTERBURY, KENT CT1 1QU - UK

Word count (main text, acknowledgements, references and figure legends): 5983 


\section{Summary}

This paper examines the contribution of products derived from baobab (Adansonia digitata), shea (Vitellaria paradoxa) and néré (Parkia biglobosa) to rural livelihoods in Burkina Faso. A survey was conducted in northern and southern regions to identify and understand the social and environmental factors influencing the utilization of tree products by rural households for home consumption and commercialisation, and to explore the contribution of tree products to food security. Emphasis was placed on the roles and responsibilities of women for tree product utilization.

Inter- and intra-household relationships governing tree foods were found to vary between regions and tree species, and with gender and household composition. Collection and utilization of tree products differed between north and south because of contrasting ecological contexts and evolving social mores. Household decision making processes were negotiated and consensual in both regions.

The results suggest that domestication and dissemination of planting and regeneration technologies, and product processing and marketing initiatives, need a gendered and tree-specific approach in order to build on local norms and capacities. Measures for the conservation and management of tree resources are most important where ecological constraints are most severe but dependence is greatest for sustaining food security. 


\section{Introduction}

Concepts of food security have evolved over recent decades, from global issues to household and individual livelihood perspectives, and from a focus on hunger and macronutrient provision towards health and micronutrient sufficiency (Maxwell, 1996; Negin et al. 2009; Miller and Welch 2013). The prevailing understanding adopted by major international organisations is that food security obtains 'when all people at all times have access to sufficient, safe, nutritious food to maintain a healthy and active life' (WHO 2015; FAO 2015).

Berry et al. (2015) argued that sustainability, in addition to the concepts of availability, accessibility and utilization, should be explicitly included as a pillar of food security. Particularly in fragile environments such as the Sahel region, where the effects of climate change are likely to impact severely on poor populations, the contribution of biodiversity to food systems and sustainability needs to be identified, preserved and strengthened (Arnold et al. 2011; Sunderland 2011; IPCC 2014; World Bank 2016).

In the Sahel, woodlands and tree foods have potential to contribute towards food security, livelihoods, and social and political security (Owusu et al. 2011; Nanama and Frongillo 2012; Ickowitz et al. 2014), adding to agricultural production at important times during the annual calendar of livelihood activities (Table 1).

\section{INSERT TABLE 1}

Land tenure is an important determinant of livelihood strategies: traditionally, in Burkina Faso, land is distributed according to ethnicity (Brasselle et al. 2002). At a village level, the land chief is responsible for allocations to each clan head, who distributes the parcels among his people. Within the family, the head of the 
compound allocates usufruct rights to his wives and sons. Traditional tenure still precedes in importance the current legislative framework (Réorganisation Agraire et Foncière) dating from the 1990s, implementation of which has been delayed and is still limited (Cotula et al. 2004; LeFaso.net 2012).

Much remains to be discovered about the gendered dimensions of tree management in Burkina, and of the dynamics underlying inter- and intra-household decision making about access to, harvesting, and utilization of tree products in the household diet and economy. Whereas consumption of tree foods is viewed generally as a food insecurity coping strategy, the reality is complex: understanding the ecological, economic and social environments that drive people's decision making becomes paramount to the success of any initiative aimed at enhancing utilization of tree foods. In particular, women's access to land and economic roles in Burkina have been shown to be complex and nuanced (Kevane and Gray 1999), with more knowledge needed to guide policy interventions.

Burkinabé cuisine consists of cereal dishes and sauces based on diverse plant species. Avallone et al. (2007) have shown that meals with traditional sauces are relatively rich in important micronutrients. Shea fruit is rich in macronutrients (Teklehaimanot 2004) and many other trees are seen as key sources of food, nutrition and health (Glew et al. 1997; Gustad et al. 2004; Arnold et al. 2011). Baobab is known for its versatility with a high nutritional content in the fruit, leaves, seeds and kernels, notably of calcium, lipids, dietary fibre and vitamins B and C (Chadare et al. 2008). The flour produced from néré seeds is rich in macronutrients. The main product, soumbala, is often used in sauces. The tree is also valued for its contribution to soil fertility and the medicinal properties of the fruit, bark, roots and leaves (Tomlinson et al. 1995; Teklehaimanot 2004). 
Understanding household context, composition and decision making is critical for policies to enhance food security (Poole et al. 2013a). In Burkina, household decision-making is also strongly influenced by social and political mechanisms which mediate differential access to natural resources (Brasselle et al. 2002). In this paper, the Mooré term zaka has been translated as 'compound' and 'complex household' (French concession). A single compound can contain up to forty people living within individual conjugal units. These conjugal units correspond to the 'household' (French ménage). A compound may comprise up to seven or more such 'households' or ménages, characterised by a hierarchy of age, gender and idiosyncratic factors. For this study, the single conjugal household has been analysed as the basic social, productive and reproductive unit.

Various modelling approaches have been developed to handle the complexities of intrahousehold relationships and decision making, to illuminate likely power, gender and intergenerational relations, and to explain management and decision making about ownership of, access to, and utilization of natural resources and products (Haddad et al. 1997). Empirical evidence in Burkina (Tincani 2012) has suggested a dynamic of negotiation and renegotiation by household members of entitlements to food and other resources with considerable differentiation between and within households in respect of gender responsibilities and seasonal food provisioning through farm production, food purchase and collection of tree foods.

The paper adopts an interdisciplinary livelihoods approach, drawing on both ecology and socio-economic concepts. It explores the interrelationship between the use of tree products and intrahousehold dynamics including gendered roles and responsibilities, and seeks further evidence for the hypothesis of negotiation as the household decision making model. We document the current patterns of access to 
primary resources, the utilization of tree products for household consumption and sale, and resource conservation practices. The intention is to add new knowledge about the roles and responsibilities of members of the conjugal households for decision making about the tree resources, and to identify implications for policy approaches towards natural resources that can sustain and enhance the contribution of tree resources to food security and livelihoods. The research focused on products of three of the most important tree species in Burkina: baobab (Adansonia digitata), shea (Vitellaria paradoxa) and néré (Parkia biglobosa).

\section{Methods}

There were two principal data collection methods: firstly, a questionnaire was designed based on themes emerging from a review of the literature; and secondly, focus group discussions were held at validation workshops. Key informant discussions were also held with local experts with whom the questionnaire was revised following testing.

Three contrasting areas of Burkina Faso were selected to capture agro-ecological and economic variation principally determined by different rainfall regimes and differential exposure to markets and trade in agrifood products. The first was in the drier northern region, more remote from national markets, with ten villages purposively selected in Passoré province. Similarly, ten villages were selected from four communes in Zoundwéogo and Nahouri provinces in the wetter southern part of the country, close to Ghana, with significant cross-border trade; ten villages were also chosen in Eastern Burkina, in Gourma province.

Purposive sampling as the framework for research design imposes analytical limitations. However, it was considered to be the appropriate method for the 
exploratory approach, being an efficient and more certain means in an insecure environment (especially closer to the northern border with Mali) to ensure that villages, households and individuals interviewed could provide rich and relevant data about the tree resources and particular intra-household management and decision making phenomena. Selection of villages within the communes was based on information from key local informants to ensure the presence of the selected trees (baobab, shea, néré). Households were also purposively selected from among those involved in a group activity or an association that collects and transforms the specific tree products, in order to understand collective behaviours in tree resources management and to consider the impact of community-level interventions promoting conservation.

Respondents were female heads of households, in order to secure a gendered perspective on tree resources and intrahousehold management.

The questionnaire was structured in six sections with both closed and open questions:

- Household social characteristics including education, age and gender structure;

- Household assets and access to services and infrastructure;

- Access to agricultural land and trees;

- Utilization of products of baobab, shea and néré respectively, focusing on the roles and responsibilities of different household members and patterns of decision making;

- Norms for harvesting, processing, consumption, access to markets and sale of tree products, and use of income; 
- Tree management, replanting and regeneration practices.

Data were collected between October-December 2013. Enumerators were recruited from three partner organizations: SEMUS in the northern town of Yako (Passoré), NATURAMA in the southern town of Nobéré (Zoundwéogo/Nahouri) and AGED in the eastern town of Fada N'Gourma (Gourma). The final questionnaire, prepared in French, was administered in Mooré. Responses were recorded in French, translated to English and analysed in Excel. Triangulation and validation of results were conducted at two regional workshops in February 2014. Workshop data were recorded in note form in French and analysed by content and compared with the questionnaire data.

Data in the east were incomplete due to problems faced by the local enumerator in the field-level implementation of the questionnaire. After cleaning, descriptive statistics in the following results refer to 180 respondents (north=100, 80=south). Percentage figures occasionally refer to a smaller total where there were missing data. Participants from the east were included in the southern validation workshop and their views have been represented in the discussion, and were found to be consistent with those from Zoundwéogo/Nahouri.

\section{Results}

The following section provides an overview of characteristics of the 180 respondents and their households.

\section{Household demography and assets}

Respondents' ages ranged from 20 to 70 years (mean=39; $s d=10.8$ ), with 9 respondents in the north and six in the south without husbands. 
There were differences between northern and southern sites in respect of household structure (Table 2): compounds in the northern sample were larger in terms of number of households (Pearson Chi-Square $p<0.0001$ ) and were more polygamous (Pearson Chi-Square $p<0.05$ ) than in the south. Patterns of land ownership were more fragmented in the north.

\section{INSERT TABLE 2}

Women's access to land was through assignment of individual plots by their husbands $(64 \%)$ or through various authority structures such as the lineage chief, land chief, village chief or head of the compound (32\%). Only one woman said she had chosen the plot by herself. All other respondents reported that they had discussed and negotiated access with their co-wives and compound head.

\section{Tree resources by household}

In the north, where agriculture is more constrained by harsh climatic conditions, the women exploited products from a greater range of trees than women in the south, in terms of quantity harvested as well as diversity of products. Access to trees was usually mediated by husbands. A consensus was evident at the validation workshop in the south that the so-called 'traditional' social customs of male control were declining, leaving women with more freedom to exploit resources and market opportunities.

\section{Baobab}

\section{Access and collection}

Collection and utilization of baobab products differed between the northern and southern regions because of contrasting contexts. Household entitlements to land, and trees were generally mediated by men, but were not rigidly controlled: outsiders 
were able to negotiate access to products of private trees to feed their families, but not for sale. Baobab on common land was for all community members on a firstcome first-served basis. In the south, women were mainly responsible for leaves and fruit collection, with $78 \%$ of the respondents and $48 \%$ of their co-wives involved.

In the north, few respondents (20\%) mentioned collecting the scarce baobab products. Secondly, in this area the participants commented that baobab is still a 'man's tree': in the north, almost all women (98\%) stated their need to ask for their husband's or chief of household's permission to collect fruit, whereas in the south, only $58 \%$ of women asked for permission before collecting.

Figure 1 illustrates the participation by different household members in baobab collection: it is evident that all household members in the north, including men and boys, were involved. In contrast, in the south the harvesting responsibility was primarily that of adult women, with help from young daughters.

\section{INSERT FIGURE 1}

During the workshops, it emerged that in the north baobab fruit and leaf collection was considered to be a man's task since the trees are tall and fruit collection by climbing was said to be dangerous and undignified for women.

\section{Utilization}

In the south, all households consumed baobab, compared to only $60 \%$ in the north, due to scarcity. Again in the south, cooking and processing the products was an activity exclusively for women, either undertaken by the respondents or their cowives, daughters-in-law or young girls. About one-third of households in both sites sold baobab leaves and pulp, either dried or fresh. 
The transformation process in the north was carried on by women, (according to $84 \%$ of the respondents), along with $42 \%$ of their co-wives, while $36 \%$ of the husbands were involved in the commercialization of baobab, especially when they faced cash needs.

Men were more involved in marketing in the north than in the south, because northern markets were more remote and transport was difficult. Most respondents (over $80 \%$ ) agreed that sales usually followed shortly after collection. The respondents (44\%) as well as their co-wives (44\%), daughters-in-law (62\%) and older daughters (age fifteen or more, $25 \%$ ), with help from husbands (25\%), decided together how much product to keep or sell.

Overall, the evidence suggested that income was kept by the male head of the household, but used towards common needs; only $17 \%$ of the women kept the money themselves. It was made clear by the women that nobody forced them to give the cash to their husband. Income was used to buy more product to process and resell (especially shea nuts, but also baobab fruits and néré powder), to start improvement works in the compound, and for general household expenses.

\section{Replanting and regeneration}

In the north, few respondents $(9 \%)$ stated that they or someone in their compound had replanted baobab. In the north, this was for the most part a matter of custom: baobab trees were said to be sacred trees that 'communicate with the land genii'. Trees should be planted by men only, and only following a specific rite. Moreover, entitlements were a matter of private property such that trees were not planted in the parklands. They were said to be difficult to grow from seed, and needed constant protection from people and animals. If women were allowed to support assisted 
natural regeneration (ANR) until the tree was strong enough, the husband or the owner of the field would subsequently assume responsibility.

The ubiquitous nature of baobab in the south meant that replanting and ANR were unnecessary.

\section{Shea}

Shea, one of the major rural income-generating products, was usually considered to be private property, linked to land tenancy. The use of fruits (the fleshy pericarp) was subject to little control: fruits were for anyone to consume as long as they left the nut (the oil-rich seed) on the ground. In both north and south, collection and processing of shea nuts were women's responsibilities almost entirely - respondents said that they shared the task with their co-wives. Although shea was said to be a 'woman's tree', workshop participants in the south commented that male participation in the utilization of the shea nuts - primarily for highly commercializable butter - was increasing.

\section{Access and collection}

Only three respondents out of 180 said that they did not collect shea products to sell or consume at home. The fruits were consumed during the soudure season before the onset of the rains, when agricultural tasks incurred major energy expenditure and when the stores of the previous year's cereals were low or exhausted. It was reiterated during the workshops that shea product handling is a women's activity and that men took no part. However, in the southern region, it was reported that men still had a role in tree management, as nearly $90 \%$ of the respondents had to ask permission from their husbands before collecting fruits. 


\section{Processing}

Transforming nuts into shea butter is almost exclusively a female activity. More than $90 \%$ of the respondents undertook the processing themselves, and in the south this was undertaken by respondents alone $(67 \%)$ or with help from co-wives $(32 \%)$ (Figure 2). In the north respondents received help from co-wives (31\%), daughtersin-law (19\%), from daughters aged 6 and over (6\%), and very occasionally, husbands (3\%).

\section{INSERT FIGURE 2}

\section{Sales}

The same women responsible for processing undertook the selection and sales of the finished product. Women included in a group or organization would sell the better product and keep the rest for home consumption. Money from sales was said to be more important than home consumption as the cash generated could contribute to the overall household wellbeing. Respondents reported that together with their cowives, and sometimes with oldest daughters and daughters-in-law, they decided when to sell the finished product, either butter or soap.

In the north, it was evident that whenever it was necessary to travel, men were more involved in product transport, partly due to limited access to bicycles and partly because women were more likely to remain close to the compound to manage household tasks and children. Sales in the north were also made directly to itinerant traders. In contrast, women in the south frequently visited the local markets, and travelled to Ouagadougou and even into Ghana (91\% of respondents and $45 \%$ of their co-wives). 
In the southern area all respondents said that they either kept all the money or shared it with co-wives or daughters-in-law. In the north, income distribution was more fragmented: all of the women kept at least part of the income, but they shared it with their co-wives (64\%), daughters-in-law (40\%), daughters (4\%) and husbands $(3 \%)$.

Shea income, like baobab income, was invested in improvements in the compound, clothes, medicine, and other household expenditures. However, during the workshop most women agreed that since they were the keepers of the shea income, they chose often to reinvest in kernels for further commercialization, or household utensils.

\section{Replanting and regeneration}

Replantation is important to maintain access to shea products, maintain tree cover and diversity, and to slow soil erosion. Whoever planted a shea tree retained specific rights to its products, both non-timber products and fuel wood. Just over half $(52 \%)$ of the women from the northern area stated that they, or someone in their compound, had planted a shea tree in the past two years. In the north, $71 \%$ of respondents planted shea in the household field, therefore obviating the need for permission.

Women from the south commented that there is an abundance of shea trees and fruit and that replantation was unnecessary. Thus only $20 \%$ of respondents stated that they, or someone in their compound, had planted a shea tree in the past two years. The few women who had replanted had asked for permission of their husbands (12\%) or negotiated access to land with their co-wives (50\%). 
Planting permissions were related to land ownership: it was reiterated that property rights were linked to where the trees are planted, as anyone who wants to plant a tree needs to inform the landowner. In fact, all the replanted trees were set in someone's personal field. Workshop participants insisted that this was not a question of definition of private property but a matter of maintaining harmonious relations with neighbours.

\section{Néré}

\section{Access and collection}

The néré tree has important cultural specificities. Workshop participants commented that it was a symbol of land ownership, strongly linked to male control. In the north it still plays a central role in customary laws on tenancy. Traditionally, planting a néré tree means wanting to own the land, and such an action might be followed by sanctions, misfortune and death. However, the discussions suggested that the increasing economic, geographical and climatic constraints, the new national laws adopted over recent years and the impact of foreign projects were leading to a progressive modification of the local tenurial and other customs.

Néré fruit was highly prized, and all the women were conscious of the importance of the fruit from a nutritional - or at least culinary - perspective. Nevertheless, in the north use of néré trees was rare: only $9 \%$ of respondents were said to collect néré products, and none of them would sell it due to the small quantity harvested. Where it was collected, the task was primarily a responsibility of women, but men and boys participated. 
In contrast, in the south, $93 \%$ of the respondents collected néré products, and $40 \%$ of them sold néré at local markets (Figure 3). There was negligible involvement by men and boys in the south.

\section{INSERT FIGURE 3}

\section{Processing}

During the dry season, soumbala provides a rich substitute for other foods. Processing the seeds of néré into soumbala and cooking or integrating it into a sauce was undertaken exclusively by women (co-wives, daughters-in-law), who also decided how much would be kept or sold. The percentage of husbands helping was lower than $5 \%$, due to social and cultural reasons and also to the division and management of household chores.

\section{Sales}

All of the women from the south stated that néré was kept and sold when either prices were higher or when the household needed cash. Women were responsible for that decision, and they claimed that they knew market prices well. They were accustomed to go to market with co-wives and daughters-in-law, walking or by bicycle; néré was sold at the local village market $(57 \%)$, at another village market $(48 \%)$, even to distant villages or larger towns $(12 \%)$. Women were able to keep this income, sharing it with the co-wives when they were part of the process, and usually reinvesting it in daily household expenses and improvements to the compound.

\section{Replanting and regeneration}

Only $5 \%$ of respondents in the north - or someone in their household - had replanted a néré tree; in contrast, $30 \%$ had replanted trees in the south. When asked about the replantation rate during the workshops, women agreed that they had not mastered 
the technique and usually failed when trying to replant from seeds; moreover, a lack of nursery facilities was reported. The various organizations working in the area concentrated on replanting shea, baobab and trees other than néré.

While co-wives and daughters-in-law were responsible for replantation, $24 \%$ of the husbands were involved, and it was they who gave permission to replant (95\%), and decide where the tree must be replanted (90\%). The principal household field was the replanting site for $75 \%$ of respondents. Everyone who replanted a tree was positive about having specific rights to its products, fruits, leaves, bark and wood.

\section{Discussion}

The results are supportive of the literature that sees its people and skills as the chief resource of the Sahel (Mortimore 2010), able to adapt to environmental challenges and successfully negotiate traditional norms of entitlements. Significant gender differences were rooted in cultural norms for different tree species.

Stakeholder discussions highlighted the important contribution of tree products to food security during the soudure season when granaries are empty and the new harvest is awaited, and how tree product utilization by women serves as a mechanism for managing exchange, marketing and consumption through the seasons.

Entitlements to trees are linked to land in complex ways. Traditional patterns of male control of tenure and practices for tree management and product commercialization are influential in the north, but some gender roles are changing, particularly in the south, where economic opportunities are increasing.

Unitary concepts of household decision making do not apply in such complex household structures, and there was no evidence of non-cooperative bargaining. 
Consensus building was achieved through negotiation, between husbands and wives, among co-wives, and between households and the wider community (Haddad et al. 1997).

The results draw attention to the indigenous skills needed to manage complex social, economic and environmental interactions. Contrary to the poverty-environment discourse that starts from the premise that poor people cause environmental degradation, local people contribute significantly to the conservation and contribution of natural resources and to sustainable rural livelihoods (Gray and Moseley 2005; Reij et al. 2009). They show how the different tree products are utilised for food security and culinary purposes as well as income generation (Avallone et al. 2007; Coulibaly-Lingani et al. 2009).

Evidence from the workshops suggested that there are unexploited opportunities for enhanced woodland management through domestication and ANR, but also that these opportunities are circumscribed by cultural norms, or 'social conservatism' (Bernard et al. 2008). This is true especially in the north where the need for sustainable exploitation is greater due to more severe ecological conditions and where tree products are also more vital to diets and livelihoods. Thus the 'social conservatism' narrative is consistent with the statistically significant differences found between compound and household structures in north and south.

The importance of studying tree resources and utilization in the less-favoured northern site illustrates the contrast with, for example, the richer agricultural southwest of Burkina, where utilization of the wide range of available trees is limited to only a few species, and conservation practices have been found to be minimal (Augusseau et al. 2006). Also, the potential for collective organisation of womens' 
activities demonstrated elsewhere is endorsed here (Kent et al. 2014; Sidibé et al. 2014).

Nested within complex and idiosyncratic household structures, gender and age factors strongly influence collaborative responsibilities and patterns of utilization. Authority structures and intrahousehold interactions govern the collection, processing, marketing and conservation practices for the different species in different ways and in different regions.

\section{Implications}

Policies and project interventions need to take into account a series of implications. Primarily, the complexity of human relationships is evident at multiple scales: between regions; at the community level where local authorities exercise a degree of control over natural resources; within a typical compound of households; among men and women within and between the constituent households; and where not just gender but also age defines productive roles and responsibilities. Above all, the consensual basis for community and household decision making provides a fertile environment for intervention and innovation.

Development initiatives should build on womens' agency and capacities to incorporate tree resources in their food and livelihood strategies. While women's other household responsibilities constrain collective enterprise, interventions such as conservation initiatives as well as product processing and marketing need a gendered and tree-specific approach in order to build on local norms and capacities (Kevane and Gray 1999). Development initiatives should recognise the agency of local people in land management and their capacity to adapt livelihood strategies to 
changing agro-ecological and institutional environments (Gray and Kevane 2001; Cotula et al. 2004).

Selective involvement of young girls - and even boys - in some of the activities is notable, with important implications for socialization generally. In particular, there are opportunities for awareness raising, for example in local schools, about the interrelationships between natural resources, conservation management, food security and economic dimensions of livelihoods (Poole et al. 2013b).

Enhancing tree product utilization is most important where tree resources are least rich but dependence is greatest for sustaining food security. Each of the three species studied has significant nutritional and commercial potential, somewhat underexploited, and highly seasonal, with imperatives for conservation and multiplication, and greater employment creation and income-earning opportunities, especially for women.

Above all, there is a need for domestication and dissemination of planting and regeneration technologies, especially in the north despite - even because of - the ecological constraints (Poole 2004). The potential for integrating woodland and agriculture can be exploited also (Wilson et al. 1998). While land tenure arrangements in Burkina are complex, and while the traditional village order prevails (Brasselle et al. 2002), ANR is a viable way of leveraging the local social norms and constraints attached to tree planting and land ownership. Thereby, local skills and knowledge can be employed to enhance agro-ecological management in fragile environments (Mortimore 2010). ANR still has to be negotiated with the primary landowner (husband, chief of household, lineage, land, village), but women are for the most part allowed to protect naturally-grown trees. Landowners do not see ANR 
as a threat because the land genii 'allowed the tree to be born in their land', and thus nobody planted it in order to claim the land for him or herself.

Considering the significance of néré, there is a need to research and expand the conservation, multiplication and dissemination of the tree.

\section{Limitations and further research}

The sampling limitations suggests caution in generalizing the findings. Survey data collection took place over a two-month period and the validation workshops within one week, outside the main harvesting seasons. The reliance on recall by respondents for data about highly seasonal and sometimes idiosyncratic phenomena means that some relevant information is likely to have been missed. Overall, comments from key informants and the results of the validation workshops suggest that there can be substantial confidence in the representativeness and validity of the data.

Modelling decision making about consumption and sale of highly seasonal tree products requires more, and more sensitive, data. Livelihood concepts were limited to natural resource-based dimensions and have not covered the diversity of strategies, including labour, migration and use of remittances which are increasingly important in Burkina, but were beyond the scope and intention of this paper. 
Figure 1

Northern site

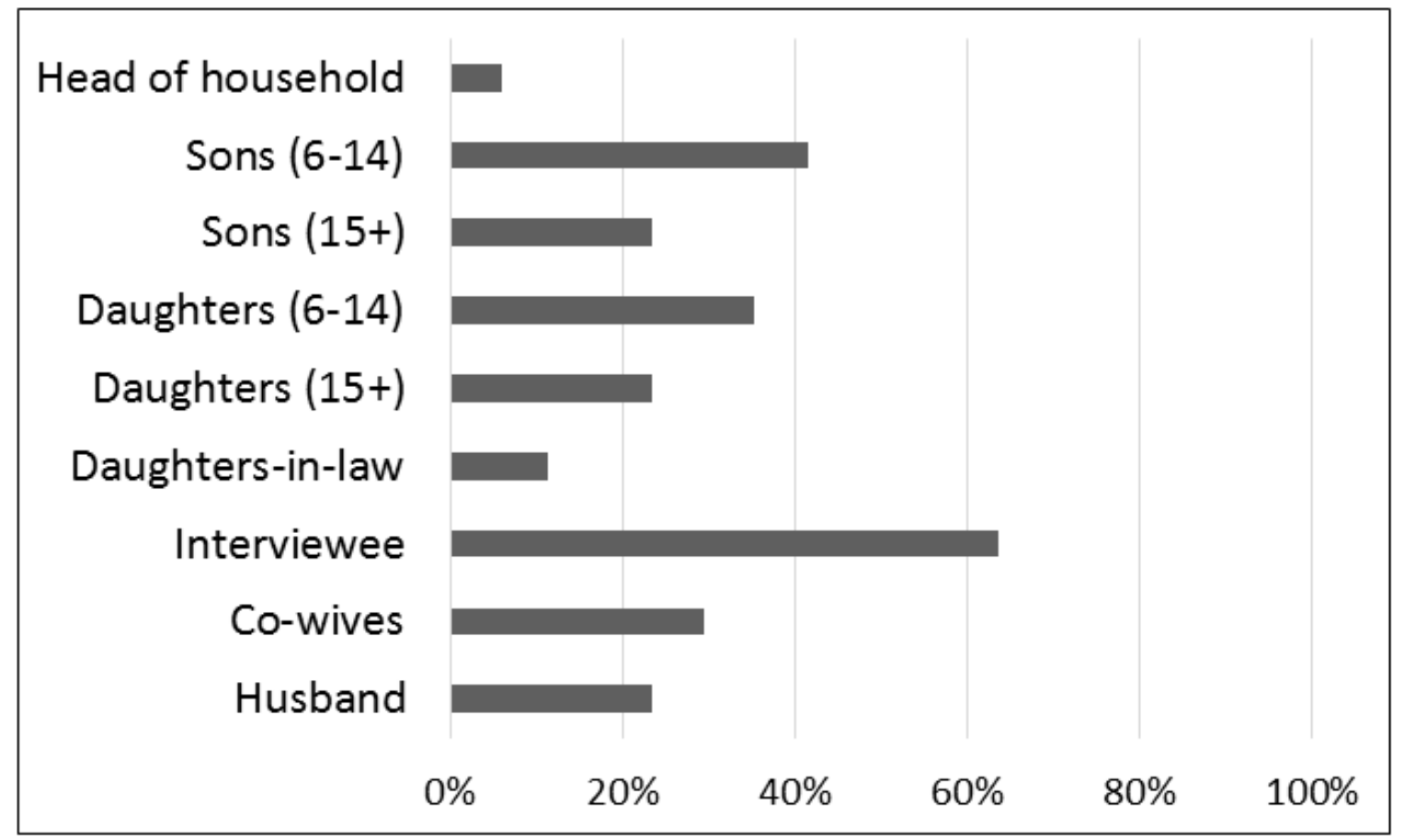

Southern site

Head of household

Sons (6-14)

Sons (15t) I

Daughters (6-14)

Daughters (15+)

Daughters-in-law

Interviewee

Co-wives

Husband I

$\begin{array}{llllll}0 \% & 20 \% & 40 \% & 60 \% & 80 \% & 100 \%\end{array}$


Figure 2

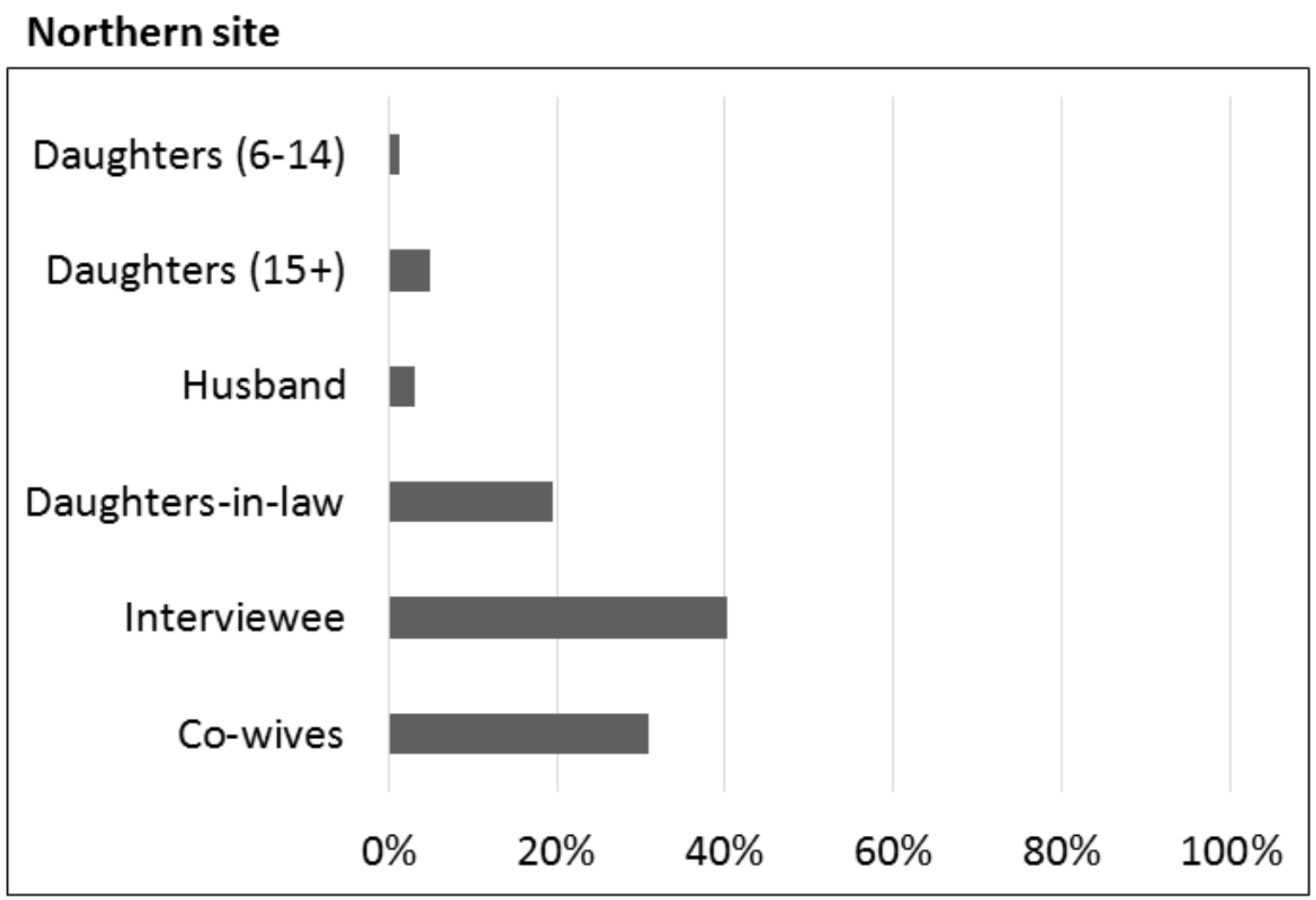

Southern site

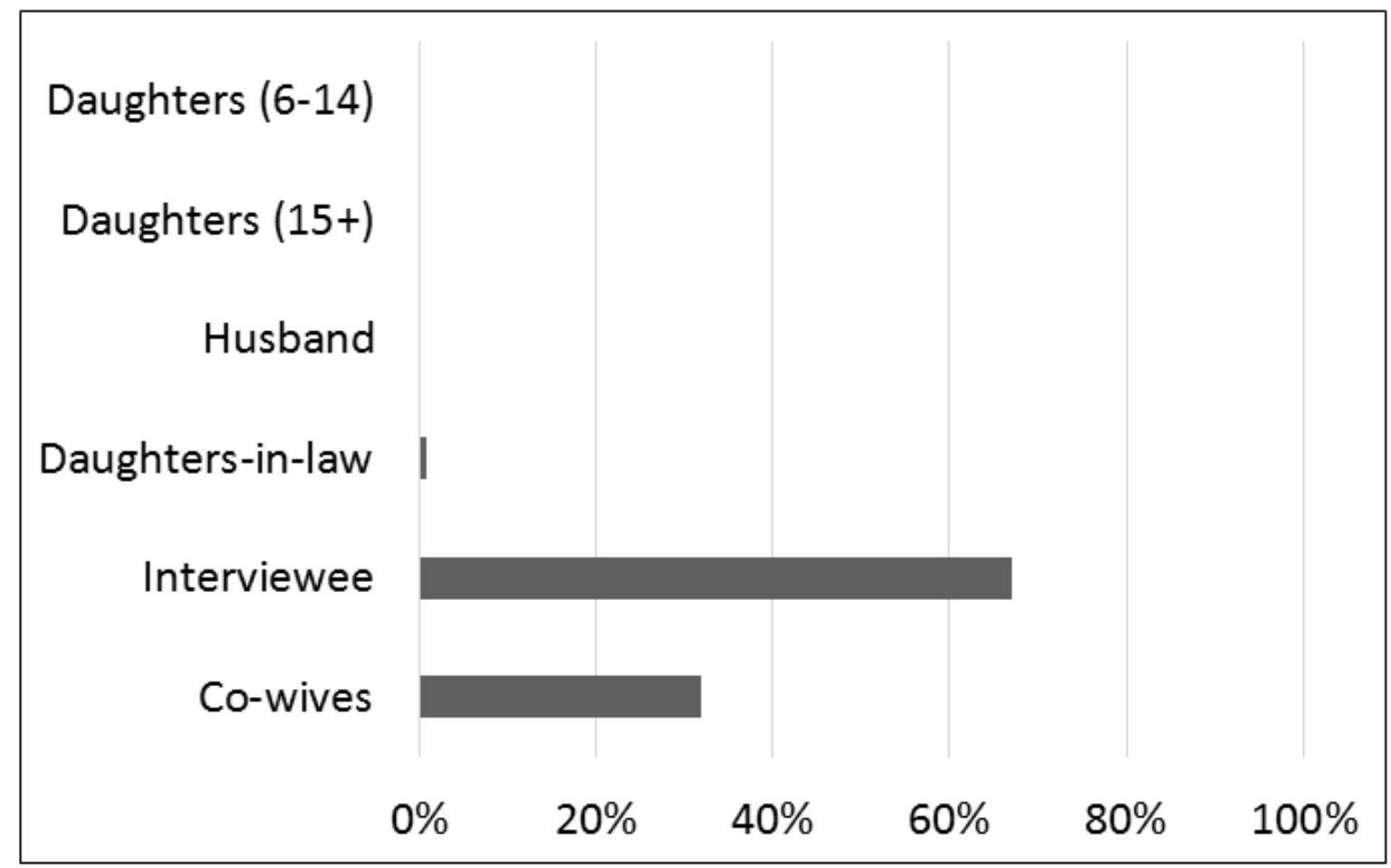


Figure 3

Northern site

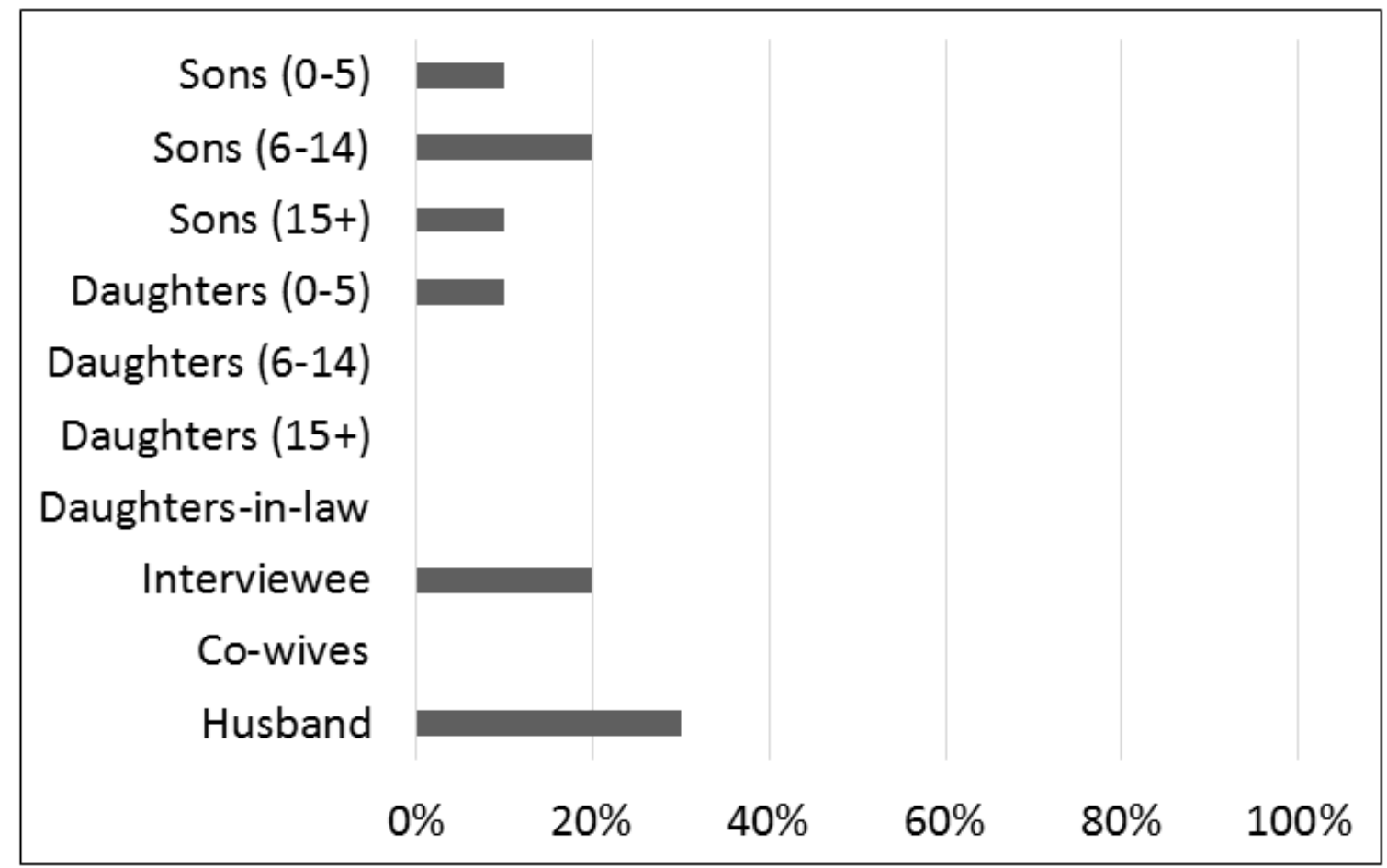

Southern site

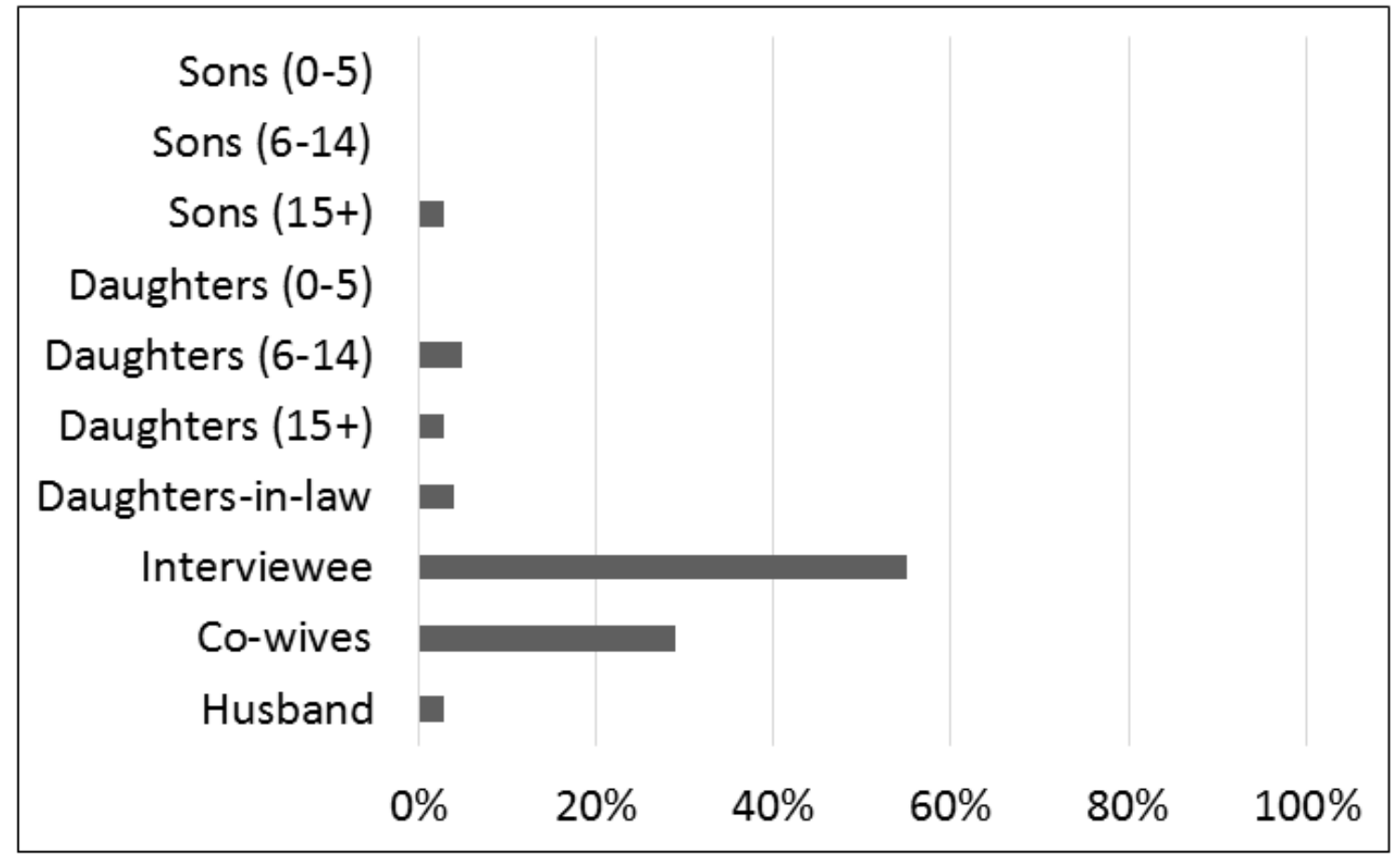




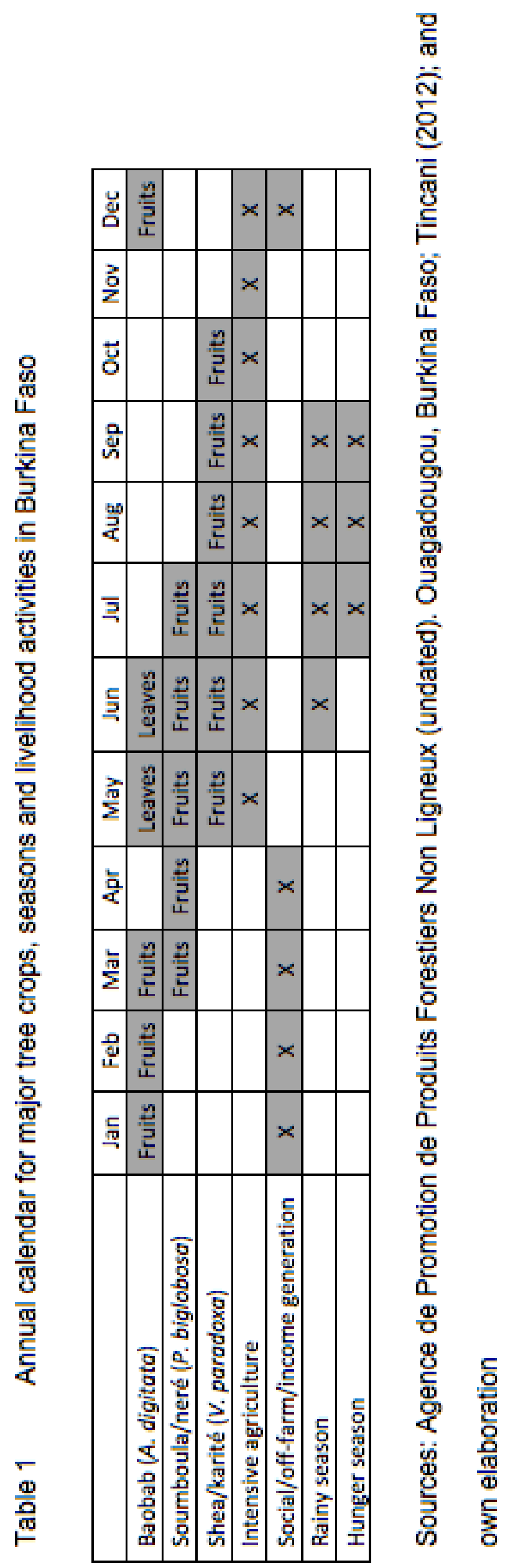


Table 2 Household demography and asset characteristics: summary descriptive statistics for northern and southern sites

\begin{tabular}{lcc}
\hline \hline Household characteristic & $\begin{array}{c}\text { North \% } \\
n=100\end{array}$ & $\begin{array}{c}\text { South \% } \\
n=100\end{array}$ \\
\hline Monogamous households & 30 & 38 \\
Polygamous (1-3 wives) & 59 & 61 \\
Polygamous (4 wives or more) & 11 & 1 \\
1 household/compound & 1 & 54 \\
2-4 households/compound & 42 & 44 \\
5 households or more per compound & 47 & 2 \\
Literate (in any language) & 32 & 23 \\
Access to electricity from solar panels & 36 & 14 \\
Access to 1 plot of land & 0 & 48 \\
Access to 2-3 plots of land & 30 & 33 \\
Access to 4-5 plots of land & 36 & 9 \\
Access to 6 or more plots of land & 34 & 0 \\
\hline \hline
\end{tabular}




\section{References}

Arnold, M., Powell, B., Shanley, P. and Sunderland, T.C.H. (2011) Editorial: Forests, biodiversity and food security. International Forestry Review 13: 259-264.

Augusseau, X., Nikiéma, P. and Torquebiau, E. (2006) Tree biodiversity, land dynamics and farmers' strategies on the agricultural frontier of southwestern Burkina Faso. Biodiversity \& Conservation 15: 613-630.

Avallone, S., Brault, S., Mouquet, C. and Trèche, S. (2007) Home-processing of the dishes constituting the main sources of micronutrients in the diet of preschool children in rural Burkina Faso. International Journal of Food Sciences and Nutrition 58: 108-115.

Becker, G.S. (1976) Altruism, egoism, and genetic fitness: economics and sociobiology. Journal of Economic Literature 14: 817-826.

Beckett, F. (2013) Researching Within-Household Distribution: Overview, Developments, Debates, and Methodological Challenges. Journal of Marriage and Family 75: 582-597.

Bernard, T., Collion, M.-H., de Janvry, A., Rondot, P. and Sadoulet, E. (2008) Do Village Organizations Make a Difference in African Rural Development? A Study for Senegal and Burkina Faso. World Development 36: 2188-2204

Berry, E.M., Dernini, S., Burlingame, B., Meybeck, A. and Conforti, P. (2015) Food security and sustainability: can one exist without the other? Public Health and Nutrition 18: 2293-2302.

Brasselle, A.-S., Gaspart, F. and Platteau, J.-P. (2002) Land tenure security and investment incentives: puzzling evidence from Burkina Faso. Journal of Development Economics 67: 373-418. 
Chadare, F.J., Linnemann, A.R., Hounhouigan, J.D., Nout, M.J.R. and Van Boekel, M.A.J.S. (2008) Baobab food products: a review on their composition and nutritional value. Critical Reviews in Food Science and Nutrition 49: 254-274.

Cotula, L., Toulmin, C. and Hesse, C. (2004) Land Tenure and Administration in Africa: Lessons of Experience and Emerging Issues. London, International Institute for Environment and Development.

Coulibaly-Lingani, P., Tigabu, M., Savadogo, P., Oden, P.-C. and Ouadba, J.-M. (2009) Determinants of access to forest products in southern Burkina Faso. Forest Policy and Economics 11: 516-524.

FAO (2015) The State of Food Insecurity in the World 2015. Rome, United Nations Food and Agriculture Organization. [www document]. URL http://www.fao.org/hunger/glossary/en/.

Glew, R.H., Vanderjagt, D.J., Lockett, C., Grivetti, L.E., Smith, G.C., Pastuszyn, A. and Millson, M. (1997) Amino acid, fatty acid, and mineral composition of 24 indigenous plants of Burkina Faso. Journal of Food Composition and Analysis 10: $205-217$.

Gray, L.C. and Kevane, M. (2001) Evolving tenure rights and agricultural intensification in Southwestern Burkina Faso. World Development 29: 573587.

Gray, L.C. and Moseley, W.G. (2005) A geographical perspective on povertyenvironment interactions. Geographical Journal 171: 9-23.

Gustad, G., Dhillion, S.S. and Sidibé, D. (2004) Local use and cultural and economic value of products from trees in the Parklands of the municipality of Cinzana, Mali. Economic Botany 58: 578-587. 
Haddad, L., Hoddinott, J. and Alderman, H., Eds. (1997) Intrahousehold Resource Allocation in Developing Countries: Models, Methods, and Policy. Baltimore and London, Johns Hopkins University Press.

Ickowitz, A., Powell, B., Salim, M.A. and Sunderland, T.C.H. (2014) Dietary quality and tree cover in Africa. Global Environmental Change 24: 287-294.

IPCC (2014) Climate Change 2014: Synthesis Report. Contribution of Working Groups I, II and III to the Fifth Assessment Report of the Intergovernmental Panel on Climate Change [Core Writing Team, R.K. Pachauri and L.A. Meyer (eds.)]. IPCC, Geneva, Switzerland.

Kent, R., Bakaweri, C. and Poole, N.D. (2014) Facilitating entry into shea processing: a study of two interventions in northern Ghana. Food Chain 4: 209-224.

Kevane, M. and Gray, L.C. (1999) A woman's field is made at night: gendered land rights and norms in Burkina Faso. Feminist Economics 5: 1-26.

Kristensen, M. and Lykke, A.M. (2003) Informant-based valuation of use and conservation preferences of savanna trees in Burkina Faso. Economic Botany 57: 203-217.

Leakey, R.R.B., Tchoundjeu, Z., Schreckenberg, K., Shackleton, S.E. and Shackleton, C.M. (2005) Agroforestry tree products (AFTPs): targeting poverty reduction and enhanced livelihoods. International Journal of Agricultural Sustainability 3: 1-23.

LeFaso.net (2012) Réorganisation Agraire et Foncière: La loi adoptée avec des $\begin{array}{llll}\text { innovations. } & \text { Ouagadougou. } & \text { dwww }\end{array}$ http://lefaso.net/spip.php?article48921. 
Maxwell, S. (1996) Food security: a post-modern perspective. Food Policy 21: 155170.

Miller, D.D. and Welch, R.M. (2013) Food system strategies for preventing micronutrient malnutrition. Food Policy 42: 115-128.

Mortimore, M. (2010) Adapting to drought in the Sahel: lessons for climate change. Wiley Interdisciplinary Reviews: Climate Change 1: 134-143.

Nanama, S. and Frongillo, E.A. (2012) Altered social cohesion and adverse psychological experiences with chronic food insecurity in the non-market economy and complex households of Burkina Faso. Social Science \& Medicine 74: 444-451.

Negin, J., Remans, R., Karuti, S. and Fanzo, J. (2009) Integrating a broader notion of food security and gender empowerment into the African Green Revolution. Food Security 1: 351-360.

Owusu, V., Abdulai, A. and Abdul-Rahman, S. (2011) Non-farm work and food security among farm households in Northern Ghana. Food Policy 36: 108118.

Poole, N.D. (2004) Perennialism and poverty reduction: knowledge strategies for tree and forest products. Development Policy Review 22: 49-74.

Poole, N.D., Chitundu, M. and Msoni, R. (2013a) Commercialisation: a metaapproach for agricultural development among smallholder farmers in Africa? Food Policy 41: 155-165.

Poole, N.D., Alvarez, F., Vazquez, R. and Penagos, N. (2013b) Education for all and for what? Life-skills and livelihoods in rural communities. Journal of Agribusiness in Developing and Emerging Economies 3: 64-78. 
Reij, C., Tappan, G. and Smale, M. (2009) Re-Greening the Sahel: Farmer-led Innovation in Burkina Faso and Niger. In: Millions Fed: Proven Successes in Agricultural Development. Eds. D. J. Spielman and R. Pandya-Lorch, pp. 5358. Washington DC, International Food Policy Research Institute.

Sidibé, A., Vellema, S., Dembélé, F., Témé, B., Yossi, H., Traoré, M. and Kuyper, T.W. (2014) Women, shea, and finance: how institutional practices in a Malian cooperative create development impact. International Journal of Agricultural Sustainability 12: 263-275.

Sunderland, T.C.H. (2011) Food security: why is biodiversity important? International Forestry Review 13: 265-274.

Teklehaimanot, Z. (2004) Exploiting the potential of indigenous agroforestry trees: Parkia biglobosa and Vitellaria paradoxa in sub-Saharan Africa. Agroforestry Systems 61: 207-220.

Tincani, L. (2012) Resilient Livelihoods: Adaptation, Food Security and Wild Foods in Rural Burkina Faso. Unpublished PhD. London, SOAS, University of London.

Tomlinson, H., Teklehaimanot, Z., Traoré, A. and Olapade, E. (1995) Soil amelioration and root symbioses of Parkia biglobosa (Jacq.) Benth. in West Africa. Agroforestry: Science, Policy and Practice 47: 145-159.

WHO (2015) Food Security. Geneva, United Nations World Health Organization. [www document]. URL http://www.who.int/trade/glossary/story028/en/.

Wilson, T.D., Brook, R.M. and Tomlinson, H.F. (1998) Interactions between néré (Parkia biglobosa) and underplanted sorghum in a parkland system in Burkina Faso. Experimental Agriculture 34: 85-99. 


\section{Figure legends}

Figure 1 Percentage data for participation by different household members and age groups by years in collection of baobab products in contrasting northern and southern sites, showing involvement of a wide range of household members including the husband, boys and girls in the north compared to predominantly adult female collection in the south.

Figure 2 Percentage data for participation by different household members and age groups by years in shea processing in northern and southern sites showing the predominance of female involvement, and illustrating collaboration in the south being almost exclusively confined to the interviewee and co-wives.

Figure 3 Percentage data for participation by different household members and age groups by years in the collection of néré in contrasting northern and southern sites, showing the greater involvement of male household members (sons and husbands) in the north compared to predominantly adult female collection in the south with collaboration at the compound level among wives. 